\title{
INTERNALISASI DAN IMPLEMENTASI NILAI-NILAI PANCASILA DALAM MEMBANGUN SIKAP TOLERANSI DI ANTARA SISWA BEDA AGAMA DI SMA NEGERI I ENDE
}

\author{
Oleh Kristoforus Kopong ${ }^{1}$
}

\begin{abstract}
Abstrak
SMA Negeri 1 Ende yang beralamat di Kelurahan Onekore, Kecamatan Ende Tengah Kabupaten Ende, merupakan salah satu sekolah yang siswanya berasal dari berbagai latar belakang yang berbeda termasuk agama. Karena itu, peneliti mengangkat tema internalisasi dan implementasi nilai-nilai Pancasila dalam membangun sikap toleransi antara siswa beda agama di SMA Negeri 1 Ende. Permasalahan dalam penelitian ini adalah bagaimanakah internalisasi dan implementasi nilai-nilai Pancasila di SMA Negeri 1 Ende dalam membangun sikap toleransi antara siswa beda agama? Penelitian ini bertujuan untuk mendeskripsikan bagaimana internalisasi dan implementasi nilai-nilai Pancasila yang dilakukan SMA Negeri 1 Ende. Hasil penelitian ini diharapkan dapat menjadi sumbangan pemikiran bagi SMA Negeri 1 Ende dalam melakukan upaya strategis untuk menginternalisasi dan mengimplementasi nilai-nilai Pancasila dalam membangun sikap toleransi antara siswa beda agama. Subyek atau narasumber dalam penelitian ini 15 orang, yang terdiri dari 8 guru dan 7 orang siswa. Teknik pengumpulan data yang digunakan adalah observasi, awancara, dan dokumentasi; sementara analisis yang digunakan adalah deskriptif kualitatif. Data observasi, wawancara dan dokumentasi dianalisis dengan menggunakan tahap-tahap reduksi data, penyajian data dan penarikan kesimpulan. Disimpulkan bahwa internalisasi nilai-nilai Pancasila di SMA Negeri 1 Ende sudah terlaksana dengan baik. Hal ini dibuktikan dengan hasil wawancara baik dengan para guru maupun siswa bahwa internalisasi atau proses penanaman nilai-nilai Pancasila sudah dilakukan dengan baik melalui kegiatan intra kurikuler (proses pembelajaran), ko-kurikuler (pendalaman materi pembelajaran), maupun kegiatan ekstra kurikuler. Demikian pun dengan implementasi (pelaksanaan) nilai-nilai Pancasila. Namun demikian dalam mengimplementasikan nilai-nilai Pancasila masih ada siswa yang belum melakukannya secara sungguh-sungguh baik di lingkungan sekolah maupun di luar sekolah atau masyarakat dimana siswa itu berada. Untuk itu diperlukan upaya limplementasi nilai-nilai Pancasila secara terprogram dan berkelanjutan agar terbangun sikap toleransi di antara siswa beda agama di SMA Negeri 1 Ende.
\end{abstract}

Kata Kunci: Internalisasi; Implementasi; Nilai-Nilai Pancasila; SMA Negeri 1 Ende

\section{PENDAHULUAN}

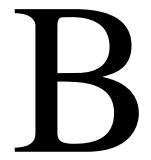

eberapa kasus intoleransi antarumat beragama belakangan ini menunjukkan belum optimalnya upaya internalisasi dan implementasi nilai-nilai Pancasila dalam kehidupan bermasyarakat, berbangsa dan bernegara. Melemahnya sikap toleransi antarumat beragama tersebut hendaknya menjadi objek kajian yang mendapat perhatian serius dari lembaga pendidikan dan para praktisi pendidikan yang berkaitan langsung dengan proses pendidikan dan pembinaan sikap toleransi di sekolah-sekolah. Sekolah hendaknya dapat menjadi medium yang dapat menumbuh-kembangkan sikap toleransi beragama. Sebab di sekolah internalisasi dan

\footnotetext{
${ }^{1}$ Dosen Pengampu Mata Kuliah Pancasila dan Pendidikan Kewarganegaraan pada Stipar Ende.
} 
implementasi nilai-nilai Pancasila dapat dilaksanakan secara terencana/terprogram, berkelanjutan dan terukur. ${ }^{2}$ Harapan ini terutama ditujukan bagi sekolah-sekolah yang mana siswanya tidak hanya terdiri dari satu agama saja, tetapi dari beberapa agama yang diakui di Indonesia.

Pendidikan di Sekolah Menengah Atas (SMA) dianggap mempunyai peranan dalam menginternalisasi dan mengimplementasikan nilai-nilai Pancasila dalam membangun sikap toleransi di antara siswa beda agama. Siswa SMA sering disebut usia pemuda. Jung menyatakan bahwa kepribadian usia pemuda harus banyak membuat keputusan dan menyesuaikan diri dengan kehidupan sosialnya. ${ }^{3}$ Orang pada usia ini dituntut mampu membuat keputusan, mengatasi hambatan, dan memperoleh kepuasan bagi dirinya sendiri dan orang lain. Pemuda ini sedang menghadapi perbedaan perlakuan orang tua, dari perlakuan kepada anak-anak menjadi perlakuan kepada orang dewasa. Dengan demikian, pendidikan sebagai bagian dari kehidupan sosial siswa SMA sangat berpengaruh kepada kepribadian siswa termasuk sikap toleransinya terhadap orang lain.

Siswa yang sedang belajar di SMA mengalami pertumbuhan dan perkembangan idealisme-idealisme sesuai dengan lingkungan tempat ia mencari ilmu. Kebebasan berfikir, kebebasan bertindak, dan kebebasan mencari sosok anutan dalam Sekolah Menengah Atas dapat dinilai menjadi titik kritis dalam mencapai jati diri generasi terdidik ini. Oleh karena itu, perlu upaya-upaya yang dapat mencegah sikap tumbuhnya sikap, perilaku, dan tindakan yang destruktif, dan meningkatkan sikap, perilaku, dan tindakanm yang konstruktif seperti toleransi terhadap sesama yang berbeda agama.

Setiap SMA perlu menanamkan nilai-nilai Pancasila dalam membangun sikap toleransi beragama pada siswanya. Siswa-siswa ini berada pada tahap peralihan antara masa remaja menuju dewasa yang sering kurang dapat mengendalikan diri dengan baik. Apabila generasi ini bisa menghargai perbedaan agama dan kepercayaan, maka akan terwujud masyarakat yang lebih toleran dan integratif, sehingga mendukung tujuan hidup berbangsa dan bernegara sebagaimana diamanatkan dalam Pembukaan UUD Negara Indonesia Tahun 1945 alinea IV. ${ }^{4}$

SMA Negeri 1 Ende merupakan salah satu di Kota Ende (Rahim Pancasila) ${ }^{5}$ yang siswanya berasal dari beberapa penganut agama, seperti Islam, Katolik, Kristen, dan Hindu. Sebagai salah satu SMA yang berada di Kota Pancasila, diharapkan dapat menginternalisasikan dan mengimplementasikan nilai-nilai Pancasila antara siswa beda agama. Dengan demikian

\section{${ }^{2}$ Alwisol, Psikologi Kepribadian Edisi Revisi, (Malang : UMM Press, 2009), hlm. 56}

4،... melindungi segenap bangsa Indonesia dan seluruh tumpah darah Indonesia dan untuk memajukan kesejahteraan umum, mencerdaskan kehidupan bangsa, dan ikut melaksanakan ketertiban dunia yang berdasarkan kemerdekaan, perdamaian abadi dan keadilan sosial...”

${ }^{5}$ Ende dijuluki kota pelajar (1970-1980) karena sejak dulu Kota Ende menjadi tempat kaum anakanak dan remaja atau kaum muda menuntut ilmu dari berbagai daerah di Kabupaten Ende maupun Kabupaten Lain di NTT. Paling tidak, keberadaan SMAK Syuradikara dan SMPK Ndao sebagai sekolah Katolik yang cukup ternama pada masa itu menjadikan kota Ende sebagai daya tarik bagi para pelajar. Selain itu, kota yang sama ini dijuluki juga sebagai Kota Pancasila karena di kota ini Presiden Pertama RI, Ir. Soekarno dibuang (14 Januari 1934- 18 Oktober 1938 ) dan di kota ini Bung Karno merenungkan butirbutir Pancasila (Tim Nusa Indah, Bung Karno dan Pancasila, Ilham dari Flores Untuk Nusantara, Ende: Nusa Indah, 2006), hlm. 4 
siswa dapat bersikap dan bertindak sesuai dengan nilai-nilai Pancasila. Meskipun SMA Negeri 1 secara kelembagaan telah berupaya untuk menginternalisasi dan mengimplementasi nilai-nilai Pancasila akan tetapi belum semua nilai Pancasila itu terinternalisasi dan terimplementasi sepenuhnya terutama terhadap siswa beda agama. Berdasarkan pengamatan (observasi) awal yang dilakukan oleh peneliti bahwa terkait dengan internalisasi dan implementasi nilai-nilai Pancasila belum sepenuhnya terlaksana dengan baik sesuai dngan apa yang diharapkan. Hal ini justru dapat mempengaruhi sikap tolerasi antara siswa beda agama.

Berdasarkan uraian di atas, maka penulis merasa tertarik untuk melakukan penelitian mengenai internalisasi dan implementasi nilai-nilai Pancasila dalam membangun sikap toleransi beragama di antara siswa beda agama di SMA Negeri 1 Ende. Rumusan masalah dalam penelitian ini adalah bagaimana upaya internalisasi dan implementasi nilai-nilai Pancasila yang dilakukan SMA Negeri 1 Ende dalam membangun sikap toleransi beragama di antara siswa beda agama? Berdasarkan rumusan masalah tersebut, maka tujuan penelitian ini adalah untuk mendeskripsikan upaya internalisasi dan implementasi nilai-nilai Pancasila yang dilakukan SMA Negeri 1 Ende. Hasil penelitian ini diharapkan dapat menjadi sumbangan pemikiran bagi SMA Negeri 1 Ende dalam melakukan upaya strategis untuk menginternalisasi dan mengimplementasi nilai-nilai Pancasila dalam membangun sikap toleransi antara siswa beda agama.

\section{METODOLOGI PENELITIAN}

Penelitian ini menggunakan metode kualitatif bersifat deskriptif dalam arti bahwa penelitian ini berfokus pada fenomena yang ada kemudian difahami dan dianalisis secara mendalam. Penelitian kualitatif adalah penelitian yang menghasilkan data deskritif mengenai kata-kata lisan maupun tertulis, dan tingkah laku yang dapat diamati. ${ }^{6}$ Penelitian ini dilaksanakan di SMA Negeri 1 Ende yang beralamat di Kelurahan Onekore, Kecamatan Ende Tengah, Kabupaten Ende. Penelitian ini dilaksanakan selama waktu 3 bulan (September s.d. November 2020. Dalam penelitian ini, penulis mengkaji setiap peristiwa yang terjadi dengan maksud agar dapat mengetahui secara jelas sesuai dengan data dan fakta di lapangan. Karena itu, penelitian ini berupaya untuk mengetahui dan menggambarkan tentang subyek atau individu yang akan diteliti khususnya yang berkenaan dengan proses internalisasi dan implementasi nilainilai Pancasila. Subyek atau dalam esponden/narasumber dalam penelitian ini, berjumlah 15 orang yang terdiri dari: Kepala SMA Negeri 1, 1 orang Guru Bagian Kurikulum, 1 orang Guru Kesiswaan, 2 orang Guru Pendidikan PKN, 3 orang Guru Agama, dan 7 orang siswa.

Jenis data yang digunakan dalam penelitian ini adalah data literatur dan lapangan. Adapun teknik pengumpulan data yang digunakan dalam penelitian ini, yaitu:

1. Observasi; observasi merupakan penyelidikakn mendalam tentang gejala sosial secara sistematis. ${ }^{7}$ Ini dilakukan untuk memperoleh data secara langsung dari sumber primer,

\footnotetext{
${ }^{6}$ Lexy J. Moeleong, Metodologi Penelitian Kualitatif, (Bandung: PT Remaja Rosdakarya, 2004) hlm. 3.

${ }^{7}$ Ida Mantra Bagoes, Filsafat Penelitian \& Metode Penlitian Sosial, (Yogyakarta: Pustaka Belajar, 2004), hlm. 82.
} 
hkususnya untuk melihat situasi proses pembelajaran sebagai proses internalisasi nilai Pancasila di SMA Negeri 1 Ende dan suasana kehidupan dan perilaku-perilaku para siswa dalam mengimplementasikan nilai-nilai Pancasila tersebut.

2. Wawancara; wawancara adalah pengumpulan data dengan cara mengajukan pertanyaan secara langsung. Teknik pengumpulan data dengan cara mengadakan pertanyaan, percakapan dan tanya jawab secara lisan dan langsung dengan tatap muka pada informan dengan menggunakan interview guide (pedoman wawancara) tujuannya untuk mengetahui mengenai masalah yang ada tidak dapat diobservasi, kemudian jawaban-jawaban responden dicatat atau direkam dengan alat perekam. ${ }^{8}$ Wawancara dalam penelitian ini dilakukan terhadap subyek penelitian atau narasumber baik itu para guru maupun siswa di SMA Negeri 1 Ende.

3. Studi Dokumentasi; studi dokumentasi merupakan teknik pengumpulan data yang berupa bahan-bahan tertulis, catatan, surat-surat penting dan lain-lain untuk melengkapi data yang diperoleh dari hasil wawancara maupun untuk kepentingan yang berhubungan dengan penelitian. Dalam penelitian ini dokumentasi adalah berupa foto-foto, tulisan, arsip dan lainlain yang ada di SMA Negeri 1 Ende

Selanjutnya, proses analisis dsecara kualitatif yang dilakukan melalui empat tahap, yaitu pengumpulan data melalui observasi, wawancara, dan dokumen, mereduksi data, menyajikan data, dan selanjutnya verivikasi data atau penyimpulan. ${ }^{9}$ Pentahapan itu perlu dilakukan dengan teliti agar memperoleh kesimpulan yang utuh.

\section{HASIL PENELITIAN DAN PEMBAHASAN}

\section{Internalisasi Nilai-nilai Pancasila yang Dilakukan SMA Negeri 1 Ende Dalam Membangun Sikap Toleransi Di Antara Siswa Beda Agama}

Pancasila sebagaimana terdapat dalam Pembukaan UUD Negara Indonesia Tahun 1945 merupakan dasar negara dan sekaligus pedoman hidup berbangsa dan bernegara di Indonesia. Sila-sila Pancasil, yaitu Ketuhanan Yang Maha Esa, Kemanusiaan yang adil dan beradab, Persatuan Indonesia, Kerakyatan yang dipimpin oleh hikmad kebijasanaan dalam permusyawaratan/perwakilan, dan Keadilan sosial bagi seluruh rakyat Indonesia mengandung nilai-nilai luhur. Nilai-nilai luhir Pancasila, yaitu ketuhanan, kemanusiaan, persatuan, kerakyatan, dan keadilan sosial perlu diinternalisasikan kepada seluruh warga bangsa Indonesia, sehingga dapat menjadi pegangan hidup dalam pergaulan di masyarakat. Menurut Fuad Ihsan dalam bukunya memaknai internalisasi sebagai upaya yang dilakukan untuk memasukkan nilai nilai ke dalam jiwa sehingga menjadi miliknya. ${ }^{10}$ Dengan demikan Internalisasi merupakan suatu proses penanaman sikap ke dalam diri pribadi seseorang melalui pembinaan, bimbingan dan sebagainya agar ego menguasai secara mendalam suatu nilai serta menghayati sehingga dapat

\footnotetext{
${ }^{8}$ Lexy J. Moeleong, Op.Cit., hlm. 67.

${ }^{9}$ Sugiono, Metode Penelitian Pendidikan Kualitatif dan D \& D, (Bandung: Alfabeth, 2014), hlm. 402

${ }^{10}$ Fuad Ihsan, Dasar-Dasar Kependidikan, (Jakarta: Rineka cipta, 1997), hlm. 155.
} 
tercermin dalam sikap dan tingkah laku sesuai dengan standart yang diharapkan. Jadi, internalisasi nilai Pancasila tidak lain adalah segala upaya yang dilakukan untuk memasukan nilai ketuhanan, kemanusiaan, persatuan, kerakyatan, dan keadilan sosial melalui proses pedidikan dan pembinaan ke dalam diri manusia Indonesia. Internalisasi nilai-nilai Pancasila tersebut akan semakin efektif jika dilakukaan dalam proses pendidikan formal. Tujuannya adalah nilai-nilai Pancasila itu dapat digunakan sebagai pegangan hidup untuk membangun toleransi terutama dengan antara siswa beda agama.

Berdasarkan hasil wawancara dengan kepala SMA Negeri 1 Ende, itu Bapak Yohanes A. Minggu, S. Pd mengatakan bahwa dalam rangka membangun sikap toleransi antara sisiwa beda agama, SMA Negeri 1 Ende secara sadar dan bertanggung jawab melakukan proses internalisasi nilai-nilai Pancasila kepada para siswa baik melalui kegiatan intra kurikulir, ko-kurikuler maupun ekstra kurikuler. Diharapkan melalu proses internalisasi ini nilai Pancasila dapat ditanamkan secara optimal ke dalam diri setiap siswa.

Dalam proses internalisasi yang dikaitkan dengan pembinaan peserta didik salah satu tahap yang mewakili proses terjadinya internalisasi, yaitu transformasi nilai-nilai. Tahap transformasi nilai merupakan suatu proses yang dilakukan oleh pendidik dalam menginformasikan nilai - nilai yang baik. ${ }^{11}$ Pada tahap ini hanya terjadi komunikasi verbal antara pendidik dan peserta didik. Dalam konteks penelitian ini transformasi nilai-nilai Pancasila ini sifatnya pemindahan pengetahuan dari pendidik ke siswanya. Nilai-nilai Pancasila, yaitu ketuhanan, kemanusiaan, persatuan, kerakyatan dan keadilan yang diberikan masih berada pada ranah kognitif peserta didik dan pengetahuan ini dimungkinkan hilang jika ingatan seseorang tidak kuat. Karena proses internalisasi tidak hanya melalui proses intra-kurikuler (kegiatan belajar mengajar) di dalam kelas tetapi juga perlu di dalami di luar kelas.

Sehubungan dengan dengan hal di atas, ibu Yayuk Herawati, S.Pd selaku Wakasek Kurikulum dan ibu Bonafentura N. Waruk, S.Pd sebagai salah satu guru PKn menjalaskan bahwa SMA Negeri 1 telah berupaya semaksimal mungkin untuk menginternalisasikan nilainilai Pancasila kepada semua siswanya dari kelas X sampai kelas XII. Internalisasi nilai Pancasila baik dilakukan dalam proses belajar mengajar melalui mata pelajaran PKn maupun mata pelajaran lain seperti pendidikan agama. Selain itu, proses internalisasi berlanjut dalam kegiatan ko-kurikuler dan ekstra kurikuler. Dalam kegiatan ko-kurikuler siswa diberi tugas untuk mengamati kehidupan sosial masyarakat di sekitar tempat tinggalnya lalu menuliskan laporan terkait dengan suasana toleransi beragama. Siswa diharapkan dapat mengambil hikmah dari kehidupan sosial untuk memperkuat keyakinannya terhadap nilai-nilai Pancasila yang sudah diajarkan di dalam kelas.

Proses internalisasi tersebut perlu dilanjutkan dalam kegiatan konkret agar siswa dapat mengkomunikasi (transaksi) nilai dalam dua arah antara siswa dan guru. Pada tahap ini pendidikan nilai dilakukan melalui komunikasi dua arah yang terjadi antara pendidik dan peserta

${ }^{11}$ Muhaimin, Strategi Belajar Mengajar, (Surabaya: Citra Media, 1996), hlm. 153. 
didik yang bersifat timbal balik sehingga terjadi proses interaksi. ${ }^{12}$ Dengan adanya transaksi nilai pendidik dapat memberikan pengaruh pada siswanya melalui contoh nilai yang telah ia jalankan. Di sisi lain siswa akan menentukan nilai yang sesuai dengan dirinya. Karena itu internalisasi nilai-nilai Pancasila perlu melewati proses transaksi nilai, seperti nilai ketuhanan, kemanusiaan, persatuan, kerakyatan, dan keadilan.

Berdasarkan wawan cara dengan bapak Drs. Stefanus Hadun (Wakasek Kesiswaan), bapak Ahmad Abubakar, S. Pd (guru agama Islam), dan ibu Jeane J. Kamagi, S.Pd (guru agama Kristen) diketahui bahwa proses internalisasi atau penanaman nilai-nilai Pancasila tidak hanya dilakukakan di dalam kelas oleh guru bidang studi terkai seperti PKn tetapi juga dilakukan di lapangan melalui kegiatan-kegiatan ekstra kurikuler. Misalnya, (a) nilai ketuhanan yang maha esa diinternalisasikan melalui memberikan kesempatan yang sama kepada para siswa yang berbeda agama untuk berdoa menurut ajaran agamanya masing-masing atau secara bergilir. (b) Nilai kemanusiaan diinternalisasi melalui berinteraksi dan berteman tanpa memilih latar berlakang suku dan agama, atau mengunjungi teman yang sakit dan menolong yang terkena musibah. (c) Nilai persatuan diajarkan melalui kegiatan bakti sosial berupa pembersihan halaman sekolah pada sore hari. Siswa dilatih untuk mengutamakan kepentingan umum daripada kepentingan pribadi. (d) Nilai kerakyatan diinternalisasi melalui proses perencanaan kegiatan ekstra kurikuler di mana siswa dapat berpendapat (bermusyawarah) untuk bermufakat dan menghasilkan suatu rancangan kegiatan yang disepakati bersama. Sedangkan internalisasi nilai keadilan menjaga keseimbangan hak dan kewajiban sebagai seorang siswa, sikap adil terhadap sesama dan menghormati hasil karya orang lain.

Proses internalisasi nilai-nilai Pancasila yang dilaksanakan di SMA Negeri 1 Ende telah dilakukan oleh lembaga dalam hal ini para guru. Diharapkan proses internalisasi tersebut dapat membangun sikap toleransi antara siswa beda agama di SMA Negeri 1 Ende. Sikap toleransi antarumat beragama adalah sikap menerima, menghargai kebebasan dan keanekaragaman beragama yang menjadi sebuah kepercayaan atau keyakinan dari golongan lain, tidak melakukan intervensi atau mencampuri urusan pihak lain. ${ }^{13}$ Proses internalisasi yang sudah dilakukan lembaga pendidikan SMA Negeri 1 Ende akan mempengaruhi aspek kognitif siswa untuk berpikir dan bersikap sesuai dengan nilai-nilai Pancasila sebagaimana yang diajarkan baik melalui proses pembelajaran tatap muka, maupun melalui kegian ko-kurikuler dan ekstra kurikuler.

Hasil wawancara dengan Maria H. Ue, Widya Tantri, Maria A. Bara, Muhamad Arifin, dan Linda sebagai siswa dari SMA Negeri 1 Ende membenarkan bahwa para guru telah menginternalkan nilai-nilai Pancasila kepada siswa-siswi. Internalisasi nilai-nilai Pancasila, seperti ketuhanan, kemanusiaan, persatuan, kerakyatan, dan keadilan sering dilakukan dalam kegiatan belajar-mengajar. Mata pelajaran yang sering berbicara dan membahas nilai-nilai Pancasila yaitu Pendidikan Kewarganegaraan (PKn). Mata pelajaran yang lain yang juga

12 Ibid.

${ }^{13}$ Rina Hermawati, Toleransi Antar Umat Beragama di Kota Bandung, Umbara: Indonesia Jurnal of Antrhropology, Volume 1. 
membahas tetang nilai-nilai Pancasila yaitu bahasa Indonesia tetang menggunakan bahasa persatuan dan juga mata pelajaran agama. Dalam mata pelajaran agama dibahas soal bagaimana beragama secara baik dan benar sesuai dengan agama yang dianut dan juga menghargai sesama teman yang berbeda agama. Proses internalisasi nilai-nilai Pancasila juga dilakukan melalui contoh atau teladan bapak dan ibu guru baik dalam proses pembelajaran maupun dalam pelbagai kegiatan ko-kurikuler dan ekstra kurikuler.

Temuan penelitian di atas menunjukkan bahwa proses internalisasi nilai-nilai Pancasila benar-benar dilaksanakan oleh SMA Negeri 1 Ende. Hal itu, juga berdasarkan pengamatan (observasi) peneliti dan studi dokumentasi berupa data yang terdapat pada bagian kurikulum dan juga jadwal pembelajaran. SMA Negeri 1 Ende sebagai lembaga pendidikan secara sadar mempersiapkan sumber daya manusia Indonesia untuk dapat hidup secara bersama-sama dalam keanekaragaman terutama agama. Lembaga pendidikan merupakan proses di mana masyarakat melalui lembaga-lembaga pendidikan dengan sengaja mentransformasi warisan budayanya yaitu pengetahuan, nilai-nilai dan keterampilan-keterampilan dari generasi ke generasi. ${ }^{14}$ Hal ini sejalan dengan amanar Undang-Undang No. 20 Tahun 2003 tentang Sistem Pendidikan Nasional bahwa pendidikan adalah usaha sadar dan terencana untuk mewujudkan suasana belajar dan proses pembelajaran agar peserta didik secara aktif mengembangkan potensi dirinya untuk memiliki kekuatan spiritual keagamaan, pengendalian diri, kepribadian, kecerdasan, akhlak mulia, serta keterampilan yang diperlukan dirinya, masyarakat, bangsa dan negara.

\section{Implementasi Nilai-nilai Pancasila Yang Dilakukan SMA Negeri 1 Ende Dalam Membangun Sikap Toleransi Di Antara Siswa Beda Agama}

Nilai-nilai Pancasila yakni ketuhanan, kemanusiaan, persatuan, kerakyatan dan keadilam merupakan nilai-nilai dasar yang bersifat abstrak dan universal. Bersifat abstrak karena tidak dapat diamati oleh panca indra. Walaupun demikian, nilai dasar tersebut berhubungan dengan tingkah laku manusia. Sedangkan bersifat universal karena menjangkau kenyataan obyektif dari segala sesuatu. Karena itu, nilai dasar belum dapat bermakna sepenuhnya apabila belum memiliki formulasi serta parameter atau ukuran yang jelas dan konkrit. ${ }^{15}$ Untuk perlu upaya untuk mengembangkannya menjadi nilai instumental dan selanjutnya menjadi nilai praksis. Nilai instrumental adalah nilai Pancasila yang sudah dikembangkan dalam pasal-pasal UUD 1945. Sedangkan nilai praksisnya nyata dalam sikap dan tindakan sehari-hari dalam kehidupan bermasyarakat, berbangsa dan bernegara.

Internalisasi nilai-nilai Pancasila (ketuhanan, kemanusiaan, persatuan, kerakyatan, dan keadilan) sebagaimana yang terlah dilakukan SMA Negeri 1 Ende masih berupa transfer ilmu yang hanya menyentuh ranah kognisi (penalaran/otak) dan belum sampai menyentuh ranah afeksi (emposi/perasaan/sikap) dan psikomotorik (keterampilan/skill). Karena itu nilai-nilai

\footnotetext{
${ }^{14}$ George F. Kneller (ed), Foundation of Education, (New York: Wiley, 1967), hlm. 63.

${ }^{15}$ Kristoforus Kopong, Membumikan Pancasila, Mengurai Benang Kusut NKRI, (Yogyakarta: WR,
} 2016), hlm. 40. 
Pancasila walaupun sudah diinternalisasi melalu beberapa kegiatan konkret seperti ko-kurikuler dan ekstra kurikuler tetapi nilai-nilai tersebut tersebut masih bersifat abstrak dan universal belum terimplementasi secara penuh. Untuk itu, perlu upaya untuk mengimplementasikan nilai-nilai yang sudah diperoleh melalui proses internalisasi dalam kegiatan intra kurikuler (belajarmengajar). Sebab tujuan dari proses pendidikan bukan sekedar sampai pada learning to know, tetapi harus berlanjut kepada learning to do, learning to be dan akhirnya sampai kepada learning live together. Oleh karena itu dibutuhkan upaya pengimplementasiannya dalam kehidupan konkret sehari-hari.

Implementasi adalah suatu tindakan atau pelaksanaan dari sebuah rencana yang sudah disusun secara matang dan terperinci. Implementasi biasanya dilakukan setelah perencanaan sudah dianggap sempurna. Menurut Nurdin Usman, implementasi adalah bermuara pada aktivitas, aksi, tindakan atau adanya mekanisme suatu sistem, implementasi bukan sekedar aktivitas, tapi suatu kegiatan yang terencana dan untuk mencapai tujuan kegiatan. ${ }^{16}$ Dalam konteks penelitian ini, nilai-nilai Pancasila yang sudah diinternalisasikan oleh SMA Negeri 1 Ende melalui proses pembelajaran perlu diimplementasikan atau dihidupi dalam kehidupan sehari-hari baik di sekolah maupun di lingkungan masyarakat.

Dari hasil wawancara dengan para siswa SMA Negeri 1 Ende diketahui bahwa secara umum implementasi nilai-nilai Pancasila sudah dilaksankan, namun masih ada juga nilai-nilai yang belum dilaksanakan secara penuh oleh siswa. Sehubungan dengan hal ini, Maria A. Bara, Filamon Carlos Paceli, dan Widya Tantri yang adalah siswa pada SMA Negeri 1 mengatakan bahwa proses internalisasi nilai-nilai Pancasila sudah berjalan dengan baik. Hal yang sama terjadi juga dalam proses implementasinya. Namun dalam tahap implementasinya belum semua siswa yang melaksanakannya dengan sepenuh hati dan sukarela. Misalnya berkaitan dengan nilai ketuhanan, masih ada siswa yang hanya melaksanakan ibadah ketika di sekolah. Selain itu, masih ada juga siswa yang hanya berteman dengan temannya yang sesuku/seetnis dan seagama serta masih ada sikap kurang toleran terhadap sesama teman yang berbeda agama. Begitu pula dengan implementasi nilai kemanusiaan, belum semua siswa yang berpartisipasi dalam membantu teman yang mengalami musibah.

Keadaan dimana belum semua siswa SMA Negeri 1 yang mengimplementasikan nilaipancasila juga disampaikan oleh Yanuarius A. Loggo dan Maria H. Ue masing-masing sebagai Ketua dan Wakil OSIS. Keduanya menuturkan bahwa para siswa pada umumnya sudah melaksanakan nilai-nilai Pancasila dalam kehidupannya sehari-hari. Tetapi masih ada siswa yang kelihatannya belum sepenuhnya melaksanakan nilai-nilai Pancasila sebagaimana diajarkan oleh bapak/ibu guru di sekolah. Dalam penggunaan bahasa masih banyak siswa yang menggunakan bahasa daerahnya di lingkungan sekolah, masih ada siswa yang enggan menerima dan melaksanakan hasil keputusan bersama, masih ada siswa yang menggunakan barang milik sekolah secara tidak bertanggung jawab dan irih terhadap kesuksesan teman lain.

${ }^{16}$ Nurdin Usman, Konteks Implementasi Berbasis Kurikulum, (Jakarta: Grasindo, 2002), hlm. 170. 
Siswa SMA Negeri 1, sebagai warga negara yang baik perlu mengimplementasikan nilainilai Pancasila yang sudah diinternalisasikannya itu. Sebab nilai Pancasila (ketuhanan, kemanusiaan, persatuan, kerakyatan dan keadilan) tidak hanya naskah mati tetapi harus menjadi nafas kehidupan bangsa Indonesia terutama generasi muda dan pelajar yang nampak dalam tutur kata, sikap dan pebuatan yang mencerminkan nilai-nilai Pancasila. Semua nilai yang terkandung dalam sila-sila Pancasila harus diimplementasikan karena sila-sila tersebut merupakan suatu kesatuan yang bulat dan utuh (Panca Tunggal). ${ }^{17}$ Toleransi antara siswa beda agama akan menciptakan kerukunan hidup beragama terutama dalam konteks bangsa yang bersifat pluralitas termasuk dalam hal beragama. Dalam konteks nilai-nilai Pancasila sebagai suatu kestuan yang organis (Panca Tunggal) sila-silanya saling berhubungan, tidak terimplementasinya salah satu nilai akan mengganggu nilai-nilai yang lain. Hal ini sejalan dengan pemikiran Notonagoro yang melihat bahwa dari sisi sitematikanya sila-sila Pancasila dan nilai yang terkandung di dalamnya benar-benar tersusun secara tertib derajat, konsep tertib tingkat, dan tertib golongan (volg orde) $;{ }^{18}$ dimana sila-sila yang berada di bawah (dimulai dari Sila Ketuhanan Yang Maha Esa) menjadi basis atau dasar bagi sila-sila yang di atasnya. Sedangkan sila-sila di atasnya merupakan realisasi atau implementasi dari sila-sila di bawahnya.

Sehubungan dengan belum semua siswa SMA Negeri 1 yang mengimplementasikan nilainilai Pancasila bapak Bonafentura N. Waruk, S.Pd (guru PKn), Feronika Hando Bata, S.Pd (guru agama Katolik), dan Ahmad Abubakar, S. Pd (guru agama Islam) menjelaskan bahwa semua nilai Pancasila sudah diajarkan di sekolah terutama pada saat proses pembelajaran. Namun, implementasinya terkadang belum sesuai dengan harapan. Kenyataan seperti ini terjadi di manamana, nilai PKn dan nilai agama hasil ujiannya baik, namun dalam pelaksanaannya belum maksimal, masih perlu upaya untuk meningkatkan aspek afeksi dan psikomotorik. Hal yang sama dikemukakan pula oleh Kepala SMA Negeri 1 Ende bapak Yohanes A. Minggu, S. Pd bahwa dari proses internalisasi nilai-nilai Pancasila sudah optimal, dan diharapkan semua siswa dapat mengimplementasikan nilai-nilai itu dengan penuh rasa tanggung jawab sebagai warga negara yang terdidik. Namun, dalam kenyataan riil di lingkungan sekolah terutama di luar sekolah masih dijumpai siswa yang belum sepenuhnya mengimplementasikan nilai-nilai Pancasila. Hal ini tentu dipengaruhi oleh banyak faktor salah satunya adalah perkembangan teknologi secara khusus internet yang menyebabkan siswa terkadang kehilangan orientasi sikap beragama dan secara khusus toleransi antara siswa beda agama.

Bedasarkan hasil penelitian dapat disimpulkan bahwa implementasi nilai-nilai Pancasila di SMA Negeri 1 Ende sudah dilaksanakan secara baik, namun ada siswa yang belum mengimplementasikan nilai-nilai Pancasila secara sungguh-sungguh. Untuk itu SMA Negeri 1 Ende perlu dilakukan upaya implementasi nilai-nilai Pancasila secara terukur. Nana Syaodih sebagaimana dikutip oleh Syaifuddin mengemukakan bahwa proses implementasi setidaknya ada

\footnotetext{
${ }^{17}$ Kristoforus Kopong, Op.Cit., hlm. 45

${ }^{18}$ Notonagoro, Pancasila Secara Ilmiah Populer, (Jakarta: Pantjuran Tudjuh, 1980), hlm. 37. Bdk. Noor Ms. Bakry, Pancasila Yuridis Kenegaraan, (Yogyakarta: Liberty, 1994), hlm. 49-50.
} 
tiga tahapan atau langkah yang harus dilaksanakan, yaitu : tahap perencanaan, pelaksanaan, dan evaluasi. ${ }^{19}$ Diharapkan dengan proses implementasi yang dilakukan secara terukur akan dapat membangun sikap toleransi antara siswa. Namun implementasi dalam kenyataanya yang sesunguhnya dapat berhasil, kurang berhasil ataupun gagal sama sekali ditinjau dari hasil yang dicapai "outcomes" serta unsur yang pengaruhnya dapat bersifat mendukung atau menghambat sasaran program. Walaupun demikian, SMA Negeri 1 Ende sebagai lembaga tetap terus berupaya untuk membentuk watak dan kepribadian siswa, sebagaimana diamanatkan dalam Undang-Undang No. 20 Tahun 2003 bahwa fungsi pendidikan nasional adalah mengembangkan kemampuan dan membentuk watak serta peradabanbangsa yang bermartabat dalam rangka mencerdaskan kehidupan bangsa, bertujuan untuk berkembangnya potensi peserta didik agar menjadi manusia yang beriman dan bertakwa kepada Tuhan Yang Maha Esa, berakhlak mulia, sehat, berilmu, cakap, kreatif, mandiri, dan menjadi warga negara yang demokratis serta bertanggung jawab.

\section{Kesimpulan dan Saran}

1. Kesimpulan

Berdasarkan hasil penelitian yang telah dipaparkan secara mendalam pada bagian terdahulu, maka dapat disimpulkan bahwa internalisasi nilai-nilai Pancasila di SMA Negeri 1 Ende dalam membangun sikap toleransi antara siswa beda agama sudah dilaksanakan dengan baik. Hal ini dibuktikan dengan hasil wawancara dengan para guru maupun para siswa. Internalisasi nilai-nilai Pancasila yakni nilai ketuhanan Yang Maha Esa, Kemanusiaan yang adil dan beradap, Persatuan Indonesia, Kerakyatan yang dipimpin oleh hikmad Kebijaksanaan dalam permusyawaratan/perwakilan, dan Keadilan sosial bagi seluruh rakyat Indonesia sudah di lakukan baik melalui kegiatan intra kurikuler (kegiatan belajar mengajar di kelas) melalui mata pelajaran PKn dan Pendidikan Agama, keegiatan ko-kurikuler melalui pendalaman materi seperti melakukan observasi kehipan sosial masyarakat terkait dengan penerapan sikap toleransi, dan ekstra kurikuler lainnya seperti bakti sosial. Hal ini didukung pula oleh data-data pada bagian kurikulim dan roster kegiatan belajar mengajar dan pantau peneliti bahwa SMA Negeri 1 Ende telah menginternalisasikan nilai-nilai Pancasila kepada para siswanya.

Sementara implementasi nilai-nilai Pancasila memang sudah dilaksanakan oleh para siswa dengan baik, namun belum semua siswa mengimplementasikan nilai-nilai Pancasila yang sudah diinternalisasikan. Masih ada siswa yang belum mengimplementasi nilai-nilai Pancasila baik di lingkungan sekolah maupun di luar sekolah. Hal ini dibuktikan dengan hasil wawancara dengan siswa yang juga dibenarkan oleh para guru bahwa masih ada siswa yang hanya menjalankan ibadah di sekolah sementara diluar sekolah tidak melaksanakannya. Demikian juga dalam pergaulan sehari-hari ada siswa yang memilih teman yang sesuku bahkan seagama. Hal lain

${ }^{19}$ Syaifuddin, Design Pembelajaran dan Implementasinya, (Ciputat: PT. Quantum Teaching, 2006), hlm. 100. 
misalnya masih ada siswa yang belum berpartisipasi dalam memberikan pertolongan kepada teman yang mengalami musibah atau bencana.

2. Saran

a. Bagi SMA Negeri 1 perlu mempertahankan bahkan mengingkatkan internalisasi nilainilai Pancasila kepada para siswa melalui program-program yang dilakukan secara bertahap dan berkelanjutan. Sedangkan dalam hal pengimplementasiannya, SMA Negeri 1 Ende perlu merancang program yang baik agar implementasi nilai-nilai Pancasila baik di sekolah maupun di luar sekolah dapat dilaksanakan secara terukur dan dapat dipantau oleh pihak sekolah melalui para guru.

b. Bagai para guru perlu memberikan telada hidup terhadap para siswa baik terutama dalam mengimplementasikan nilai-nilai Pancasila baik di dalam kelas maupun di luar kelas bahkan di tengah-tengah hidup bermasyarakat.

c. Bagi orang tua perlu mendukung program kegiatan yang ditawarkan oleh sekolah terkait dengan peningkatan internalisasi dan implementasi nilai-nilai Pancasila. Orang tua juga perlu mendorong anak-anaknya agar dapat mengimplementasikan nilai-nilai Pancasila baik di rumah maupun di lingkungan masyarakat.

d. Bagi siswa agar selalu membiasakan diri untuk mengimplementasi nilai-nilai Pancasila secara sadar dan bertanggung jawab demi pembentukan karakter yang selalu memiliki sikap toleransi terhadap sesama terutama terhadap sesama yang beda agama. 


\section{DAFTAR PUSTAKA}

Alwisol, 2009. Psikologi Kepribadian Edisi Revisi. Malang : UMM Press.

Bagoes, Ida Mantra, 2004. Filsafat Penelitian \& Metode Penlitian Sosial. Yogyakarta: Pustaka Belajar.

Bakry, Noor Ms., 1994. Pancasila Yuridis Kenegaraan. Yogyakarta: Liberty.

Ihsan, Fuad, 1997. Dasar-Dasar Kependidikan. Jakarta: Rineka cipta.

Kneller, George F. (ed.), 1967. Foundation of Education. New York: Wiley.

Kopong, Kristoforus, 2016. Membumikan Pancasila, Mengurai Benang Kusut NKRI. Yogyakarta: WR.

Moeleong, Lexy J., 2010. Metodologi Penelitian Kualitatif. Bandung: PT Remaja Rosdakarya.

Muhaimin, 1996. Strategi Belajar Mengajar. Surabaya: Citra Media.

Notonagoro, 1980. Pancasila Secara Ilmiah Populer. Jakarta: Pantjuran Tudjuh.

Nurdin, Syaefuddin dan M. Usman Basyiruddin, 2003. Guru Profesional \& Implementasi Kurikulum. Jakarta: Ciputat Press.

Sugiono, 2014. Metode Penelitian Pendidikan Kualitatif dan D \& D. Bandung: Alfabeth.

Syaifuddin, 2006. Design Pembelajaran dan Implementasinya. Ciputat: PT. Quantum Teaching.

Tim Nusa Indah, 2006. Bung Karno dan Pancasila, Ilham dari Flores Untuk Nusantara, Ende: Nusa Indah.

Usman, Nurdin, 2002. Konteks Implementasi Berbasis Kurikulum Jakarta: Grasindo.

Hermawati, Rina Toleransi Antar Umat Beragama di Kota Bandung, Umbara: Indonesia Jurnal of Antrhropology, Volume 1. 